DOI: $10.32604 / \mathrm{jrm} .2022 .018811$

REVIEW

\title{
Recent Technologies for the Extraction and Separation of Polyphenols in Different Plants: A Review
}

\author{
Yingying Hu ${ }^{1, \#}$, Bowen Yan ${ }^{1, \#}$, Zhefan Stephen $\mathrm{Chen}^{2}$, Lei Wang ${ }^{3}$, Wei Tang ${ }^{1}$ and Caoxing Huang ${ }^{1, *}$ \\ ${ }^{1}$ Co-Innovation Center for Efficient Processing and Utilization of Forest Products, College of Chemical Engineering, Nanjing \\ Forestry University, Nanjing, China \\ ${ }^{2}$ Nexus of Rare Neurodegenerative Diseases, School of Life Sciences, Faculty of Science, The Chinese University of Hong Kong, Hong \\ Kong, China \\ ${ }^{3}$ College of Food Science and Engineering, Ocean University of China, Qingdao, China \\ *Corresponding Author: Caoxing Huang. Email: hcx@njfu.edu.cn \\ "Yingying $\mathrm{Hu}$ and Bowen Yan contributed equally to this work, regarding as the first author
}

Received: 19 August 2021 Accepted: 24 September 2021

\begin{abstract}
Polyphenol is an important secondary metabolite with unique physiological functions and biological activity. The polyphenols in different plants and biomass have different chemical structures, which needs various extraction methods to obtain them. Recently, plant polyphenols and their application research in food and medicine have become a research hotspot, which is mainly focused on preparation, purification, structural identification, and biological activity assays. Among these researches, extraction and separation are the key sections to investigate the structure and activity of polyphenol. Hence, this review summarized the recent extraction and separation techniques of polyphenol, including solvent extraction, supercritical fluid extraction, ultrasonic extraction, enzymatic extraction, resin adsorption extraction, and electric field method, etc. In addition, this review also reveals the current problems and proposes future extraction research of polyphenol. It is hoped that this review will provide a guide for the researchers who are actively committed to promoting progress in the field of polyphenolics.
\end{abstract}

\section{KEYWORDS}

Plants; polyphenols; extraction; separation

$\begin{array}{ll}\text { Nomenclature } \\ \text { SFE } & \text { Supercritical fluid extraction } \\ \text { SCF } & \text { Supercritical fluid } \\ \text { PEF } & \text { Pulsed electric field } \\ \text { PLE } & \text { Pressurized liquid extraction } \\ \text { HHPE } & \text { High hydrostatic pressure extraction } \\ \text { HVED } & \text { High voltage electrical discharges }\end{array}$




\section{Introduction}

Polyphenol is the secondary metabolites product in the cell wall of the plant. Generally, polyphenol is referred to the aromatic compounds containing different amounts of hydroxyl groups, which is linked by the glycoside or free glycosides [1]. According to the chemical structure of polyphenol, it can be divided into flavonoids (flavonol, isoflavones, anthocyanin), phenolic acid, tannin, and lignin [2]. For polyphenol, it possesses biologically active substances having an antioxidant activity, which has been regarded as the "seventh type nutrient" for health [3]. Since polyphenol has a variety of biological activities such as antioxidation, antibacterial, anti-inflammatory, anti-tumor, it has been widely used in preventing oral infections, hypophysis sugar, lowering blood pressure, neuroprotection and, prevention of cardiovascular diseases [4-6]. In addition, polyphenol also plays an extremely important role in the growth of fruits and vegetables, such as plant defense, mediated growth, antioxidant activity, removal of free radicals, and signaling [7]. Therefore, the plants of fruits, vegetables, grains, and tea are the main source of polyphenol, especially for the dark fruits, vegetables, and cereals, plants seeds, fruit, peel, ribs, and roots [8].

In the cell wall of the plant, even some of the polyphenol exists in the form of dissociation, the most of existed polyphenol is linked with carbohydrate or lignin [9,10]. Hence, different extraction and purification should be carried out. Commonly, the used technologies for polyphenol extraction include solvent extraction [11], ultrasonic auxiliary extraction [12], microwave-assisted extraction [13], enzymatic extraction [14], and the combined methods [15]. Among these technologies, solvent extraction is the earliest and classic method for preparing polyphenol. The used solvents of acidic methanol, ethanol, or water can show the ability to dissolve the polyphenol in the liquid phase under different conditions [11]. For ultrasonic extraction, the ultrasonic wave had the abilities of penetration capacity and cavitation, which can result in the liquid molecules with performances of collisions and interactions to rapidly rupture the plant cell walls to release phenolic compounds [16,17]. Therefore, the ultrasonic extraction method is simple, low instrument cost, efficient than other technologies [18,19]. For microwave-assisted extraction, it has also been widely concerned in the extraction of biologically active substances from plant materials with advantages of high efficiency, low energy consumption, and process easy control [20]. Microwaves can penetrate the cell wall of a plant, so that the internal polar molecules absorb microwave energy, resulting in internal heat and cell structure destruction, which can promote the intracellular polyphenol to rapidly spread in the solvent at lower temperatures [21]. The enzymatic extraction is a new technique that can prepare the polyphenol with the maximum retention of activity. Generally, the carried-out conditions are gentle, highly efficient, and environmentally friendly, but the cost is high [16]. The high-pressure pulse electric technology has also been caused for the extraction of polyphenol in the plant. It can discharge and change the permeability of plant cells for dissolving of polyphenol by high-voltage current, which is an extraction technology that enables the polyphenol within the cell cells to effectively flow out [22].

Due to the structural diversity of polyphenol and the complex interior structure of the plant's cell wall, different extraction technologies should be adaptively applied for the different plants. In addition, new extraction technologies have also been proposed with the rapid development of technology. Hence, it is necessary to summary the classical and new extraction technologies for prepare the polyphenol from different plants. In this review, the recent extraction techniques of solvent extraction, supercritical fluid extraction, ultrasonic extraction, enzymatic extraction, resin adsorption extraction, and electric field method were comprehensively summarized. In addition, the current problems and prospects for the future extraction research of polyphenol were also proposed.

\section{The Plants Contained Polyphenol}

For the structures of polyphenol in different plants, both of them contain a similar structure of phenol as the framework. According to the different amounts of benzene rings and functional groups in polyphenol, it 
can be divided into categories of flavonoids, flavonol, phenolic acid, isoflavones, anthocyanins, and stilbene [23]. The basic structure diagrams of the main polyphenol in plants are shown in Fig. 1.

(a)<smiles>O=c1cc(-c2ccccc2)oc2ccccc12</smiles>

(d)

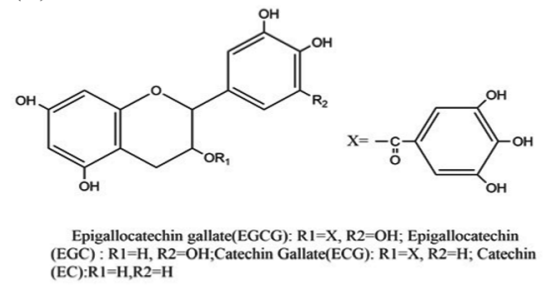

(b)<smiles></smiles>

(e)<smiles>[R]C1Cc2c(O)cc(O)cc2OC1c1ccc(O)c(O)c1</smiles>

(c)<smiles>[R9]c1c(O)cc2occ(-c3ccc(O)cc3)c(=O)c2c1[R]</smiles>

Soybean daidzein: $\mathrm{R}_{1}=\mathrm{H}, \mathrm{R}_{2}=\mathrm{H}$; Genistein: $\mathrm{R}_{1}=\mathrm{H}$, $\mathrm{R}_{2}=\mathrm{OH} ;$ Daidzein: $\mathrm{R}_{1}=\mathrm{OCH}_{3}, \mathrm{R}_{2}=\mathrm{H}$

(f)

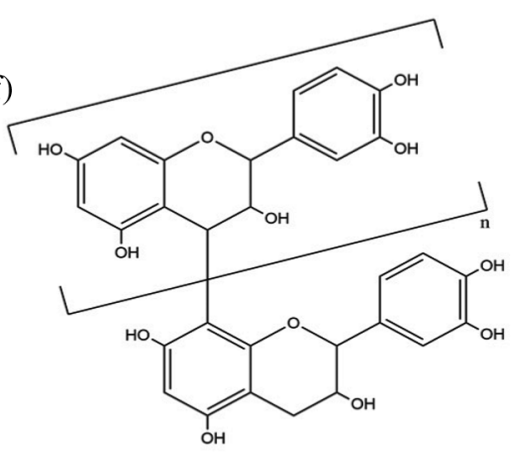

Figure 1: The basic structure diagrams of the main polyphenol in plants. (a) flavonoids 2-Phenylchromone, (b) proanthocyanidins, (c) soy isoflavones, (d) tea polyphenols, (e) apple polyphenols, (f) grape polyphenols

In the plant kingdom, about 8000 kinds of polyphenols and their derivatives have been found in various plants [24]. The common polyphenols in the different plants are listed in Table 1. It can be seen that both fruits, vegetables, and plants contain polyphenol. Hence, these substances have been regarded as the important raw materials to prepare the polyphenol, which has been regarded as the health products and medicines.

Table 1: Source of common phenolic compounds

\begin{tabular}{|c|c|c|c|}
\hline Type & Representative compound & Plant source & References \\
\hline Flavonoids & $\begin{array}{l}\text { Apigenin, Luteolin, } \\
\text { Diosmetin, Chrysin }\end{array}$ & $\begin{array}{l}\text { Celery, Sweet pepper, Pistacia vera L., } \\
\text { Caryophyllaceae, Citrus }\end{array}$ & {$[25-28]$} \\
\hline Flavonol & $\begin{array}{l}\text { Kaempferol, Quercetin, } \\
\text { Myricetin }\end{array}$ & Tomato, Onion, Carrot, Arabidopsis & {$[29,30]$} \\
\hline Phenolic acid & Coffee acid, Ferulic acid & Coffee, Tea, Walnut, Cereals & [31-33] \\
\hline Isoflavones & $\begin{array}{l}\text { Isoflavoues aglycone, } \\
\text { Genistein }\end{array}$ & Soy, Peanuts & {$[34,35]$} \\
\hline Anthocyanins & $\begin{array}{l}\text { Anthocyanin, Catechin, } \\
\text { Gallic acid }\end{array}$ & $\begin{array}{l}\text { Wine, Tea, Nuts, } \\
\text { Purple Pepper }\end{array}$ & [36-39] \\
\hline Stilbene & Resveratrol & Vintage, Celery, Rice & {$[40,41]$} \\
\hline
\end{tabular}

\section{Extraction of Polyphenols from Plant and Biomass}

A serial of technologies has been reported for the extraction of polyphenols from plant and biomass, including solvent extraction, supercritical fluid extraction, ultrasonic extraction, enzymatic extraction, 
resin adsorption extraction, and pulsed electric field method. Hence, the recent work for polyphenol isolation by these technologies is comprehensively reviewed in this section.

\subsection{Solvent Extraction}

Solvent extraction is the most widely used method of polyphenol isolation, and it is divided into two methodologies: aqueous solvent extraction and organic solvent extraction (Fig. 2). The Soxhlet extraction unit is a type of solvent extraction. The principle of these approaches considers the similarity between the desired polyphenols and the chosen extraction medium. Given that polyphenols are polyhydroxy compounds, they are typically soluble in water, alcohols, and aldehydes. Commonly used solvents for organic solvent extraction include aqueous methanol, ethanol, and acetone with a fraction of $60 \%-70 \%$ in volume. Akowuah et al. [42] found that when the solvents with different polarities were used to extract polyphenols from the powder of Orthosiphon stamineus leaves, the components and contents of the isolated polyphenols were significantly different, indicating that the selection of extractant has a great influence on the yield and properties of obtained polyphenols from Orthosiphon stamineus leaves. Ćujić et al. [43] used the ethanol extraction method to extract polyphenols from dried cherry, and the results showed that the extraction rate of polyphenols reached the highest at $27.8 \mathrm{mg} / \mathrm{g}$ when ethanol concentration was $50 \%$, cherry particle size was $0.75 \mathrm{~mm}$ and the solid-liquid ratio was $1: 20(\mathrm{~m} / \mathrm{v})$. It is noteworthy that the concentration of ethanol in the extraction medium has a great impact on the yield of polyphenols. Ramón-Gonçalves et al. [44] used the ethanol-water solvent to extract polyphenols from waste coffee grounds and found that the temperature-extraction solvent and time-extraction solvent interactions have an important effect on gallic acid, chlorogenic acid, caffeine, and p-coumaric acid areas. The optimum extraction conditions are not homogeneous for all the polyphenols. The optimal conditions $\left(60^{\circ} \mathrm{C}, 15 \mathrm{~min}\right.$ and ethanol-water mixture $\left.25: 75(\mathrm{v} / \mathrm{v})\right)$ for extracting polyphenols were determined using chromatography and stoichiometry analysis. However, when ethanol alone was used for the extraction, a more purified fraction was obtained but the extraction rate was found to be decreased. Patial et al. [45] used Fourier transform infrared spectroscopy and gas chromatography-mass spectrometry techniques to quantify the crude extracts of the four solvents extracted by the Soxhlet and ultrasonic methods. The soxhlet method gave better yields than the ultrasonic method.

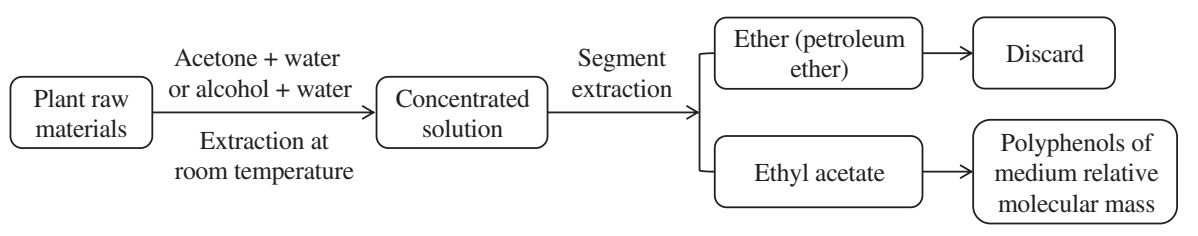

Figure 2: Solvent extraction and separation of polyphenols in plants

Aqueous solvent (methanol, ethanol, and acetone) extraction of plant polyphenols has been reported as early as the 1990s. This method has been widely used because of its simple procedures, low cost, and high isolation purity, although the extraction rate is relatively low. Moreira et al. [46] demonstrated the antibacterial effect against different bacteria and yeast of polyphenols isolated from the subcritical water extraction (SWE) of grapevine. Cova et al. [47] also studied the effect of SWE on the extraction of chicory polyphenols. They found that the maximum recovery rate of polyphenols in fresh chicory was $3 \mathrm{~g}$ gallic acid equivalent per kg. Furthermore, the overall steps took only $15 \mathrm{~min}$ in a batch-wise manner, whereas the conventional extraction required $240 \mathrm{~min}$ to achieve the comparable result. This study further demonstrates the high efficiency of SWE.

Although water can be used as the solvent for plant polyphenols, it does not apply to all kinds of polyphenols due to some reasons, including the fact that the presence of hydrogen bonding and 
hydrophobic bonds enables the formation of stable molecular complexes between polyphenols and proteins or polysaccharides. Therefore, the extraction of polyphenols should consider not only the solvent compatibility but also the various forms of interactions between target polyphenols and substances they naturally associate with inside the biomass. Researchers have demonstrated that a biphasic extraction fluid that includes organic solvent and water is the most suitable method for the extraction of polyphenols, with the most favorable amount of organic solvent generally being $50 \%-70 \%$ [48-51]. Although organic solvents and water can be used effectively to extract phenolic compounds, there remain significant mass transfer hurdles due to the complex intertwined makeup of biomass cell walls. Therefore, mechanical energy, namely ultrasonic-assisted and supercritical extraction methods, was incorporated to provide new angles to extract polyphenols with greater yields, rates, and efficiencies.

\subsection{Supercritical Fluid Extraction}

Supercritical fluid extraction (SFE) is a relatively new extraction and separation technique applied to biomass for polyphenol isolation. For a given substance there is usually an essential temperature and an indispensable pressure, above which the substance does now not end up a liquid or a gas, which is the critical point. In the vary above the critical point, the country of the depend lies between that of a gas and a liquid, and the fluid inside this vary is recognized as a supercritical fluid. Supercritical fluids have sturdy penetrating energy comparable to gases and a larger density and solubility comparable to liquids, and have properly solvent properties, permitting them to be used as solvents for extraction and separation of monomers. The procedure involves the use of supercritical fluid (SCF) as the extraction medium to achieve a high boiling point and obtain heat-sensitive components. The SCF can be used as an effective extractant due to its high density, low viscosity, and medium diffusion coefficiency [52]. Up until now, non-toxic $\mathrm{CO}_{2}$ fluid is the most frequently used supercritical fluid of choice. The schematic diagram of the supercritical fluid extraction apparatus is shown in Fig. 3 [53].

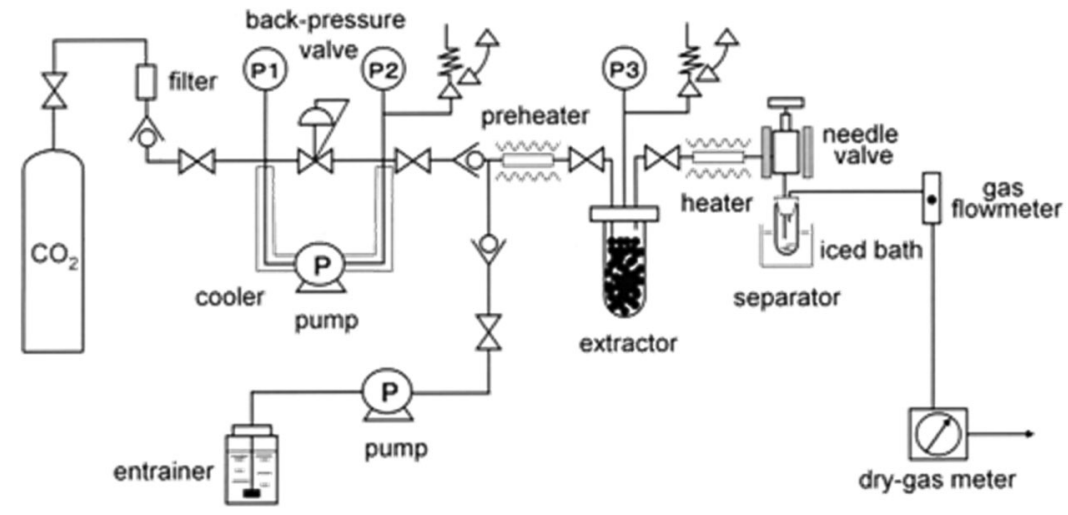

Figure 3: Schematic diagram of the supercritical fluid extraction apparatus

Escobedo-Flores et al. [54] investigated the effect of pressure and temperature on the SCF of polyphenols, antioxidant capacity, and total polyphenolic content in oats (Avena sativa L.). The polyphenols, TPC (1.25 mg GAE/g oats) and ORAC (117.88 $\mu \mathrm{mol} \mathrm{TE} / \mathrm{g}$ oats) were found to have the highest yields at $38 \mathrm{MPa}$ and $55^{\circ} \mathrm{C}$. The predicted maximum polyphenol content was $1437.57 \mu \mathrm{g} / \mathrm{g}$. In addition, a correlation was found between polyphenols and antioxidant capacity, especially with ORAC. Buszewski et al. [55] used SCF for the extraction of polyphenols from Lupinus luteus seeds. This was carried out under optimal extraction conditions $\left(73^{\circ} \mathrm{C}, 147\right.$ bar, $16.1 \%$ co-solvent $)$ and the obtained polyphenols showed appropriate chemical composition and great biological activities. The extraction rate of polyphenols was $3.25 \%$ and the content was $14.56 \mathrm{mg} / \mathrm{g}$. Aresta et al. [56] found that SFE showed 
higher recoveries when compared to the conventional solid-liquid extraction processes (including transresveratrol, $\beta$-sitosterol, $\alpha$-tocopherol (vitamin E), and ascorbic acid (vitamin C)), except for $\beta$-sitosterol and $\alpha$-tocopherol from seeds, which require a concentrated extraction cycle. Phan et al. [57] used SFE to extract polyphenols from Vietnamese Callisia fragrans (C. fragrans) with the following optimal extraction conditions: ethanol concentration of $14 \%, \mathrm{CO}_{2}$ flow rate of $20 \mathrm{~g} / \mathrm{min}$, extraction temperature of $45^{\circ} \mathrm{C}$, and pressure of $200 \mathrm{bar}$, and reported that SFE is suitable for industrial production. Supercritical fluid extraction is an efficient and environmentally friendly extraction method, which has been widely used in laboratory research and the development of products with high heat sensitivity and added value. However, due to its high cost in the extraction process [58], SFE is not suitable for the industrial extraction of plant polyphenols.

\subsection{Ultrasonic Extraction Method}

The important theoretical groundwork of ultrasonic extraction is the cavitation effect, thermal effect, and mechanical impact of ultrasound. When massive electricity ultrasound acts on the medium, the medium is torn into many small cavities, which shut without delay and generate an immediate strain of up to countless thousand atmospheres, the cavitation phenomenon. The bursting of tiny bubbles in ultrasonic cavitation generates wonderful pressure, which motives the rupture of plant phone partitions and the total organism to be finished in an instant, shortening the fragmentation time. At an equal time, the vibration impact generated using ultrasonic waves enhances the release, diffusion, and dissolution of intracellular substances, consequently drastically enhancing the extraction efficiency. These forces are generated from an ultrasonic bath which develops micro-gas nuclei produced by ultrasonic waves [59]. Ultrasonic technology has been widely applied in the research field of natural plant extraction. Ding et al. [60] found that ultrasonic extraction could significantly improve the extraction rate of polyphenols from rapeseed meals, but it would cause a series of oxidation reactions that might reduce the antioxidant properties of polyphenols. Therefore, nitrogen protection was necessary to assist the extraction. The optimal extraction conditions were: material-to-liquid ratio of $1: 30(\mathrm{~g} / \mathrm{mL})$, ultrasonic extraction time of $30 \mathrm{~min}$, extraction power of $240 \mathrm{~W}$, and nitrogen flow rate of $5 \mathrm{~L} / \mathrm{min}$. This method not only improved the extraction rate but also retained the high antioxidant activity of the isolated polyphenols. Oroian et al. [61] used the ultrasonic method to extract Crude Pollen polyphenols and determined the optimal process conditions: $100 \%$ amplitude of ultrasonic treatment, $30 \mathrm{~g} / \mathrm{L}$ solid/liquid ratio, $40.85^{\circ} \mathrm{C}$, and $14.30 \mathrm{~min}$, which led to the extraction of $366.1 \mathrm{mg} \mathrm{GAE} / \mathrm{L}$ of TPC and $592.2 \mathrm{mg} \mathrm{QE} / \mathrm{g}$ of TFC, and also to an extraction yield of $1.92 \%$. Zhao et al. [62] and Grigoraki et al. [63] used the ultrasonic method to extract polyphenols from different varieties of grape pomace and Saloia fruticosa, respectively, which also showed excellent results. Taken together, the ultrasonic extraction method is generally of great assistance to the independent solvent extraction process and can greatly improve the kinetics and yield of polyphenol extraction. It is an effective method that can not only reduce time and energy consumption but also avoid the interference of high temperature on the bioactive components.

\subsection{Microwave Extraction Method}

Microwave extraction technology describes the use of electromagnetic fields generated by microwaves to accelerate the diffusion of polyphenols from the inside of the plant to the solvent, thus effectively preventing plant polyphenols from being destroyed by oxidation at high temperature. Microwave extraction of plant polyphenols has been widely used because of its highly efficient, cheap, and environmentally friendly properties. The use of microwave technology in combination with the traditional solvent heating method makes the plant to be heated uniformly in a short time, the extraction rate is therefore accelerated and the impairments on the isolated polyphenols were effectively prevented. Conventional thermal extraction is carried out by heat conduction and thermal radiation from the outside in, while microwave extraction is heated simultaneously inside and outside through both dipole rotation 
and ion conduction. Compared with conventional thermal extraction and conventional thermal extraction, microwave extraction has the advantages of high quality, high yield, high selectivity of extracts, timesaving, less solvent usage (can be $50 \%$ to $90 \%$ less than conventional methods), low energy consumption, etc. Microwave radiation technology in the food extraction industry and the chemical industry on the application of research, although the start of only a few years, but the research results and application results have been sufficient to show its superiority: a, fast reaction or extraction; b, high yield, good product quality; c, convenient post-processing; d, safety; e, no pollution, belong to the green engineering; $f$, the composition of the production line is simple, saving investment.

Angoy et al. [64] used microwave-assisted centrifugation for the extraction of lettuce polyphenols and found that this process was able to shorten the extraction time, improve the recovery of target compounds, and was environmentally friendly. Nguyen et al. [65] used microwave-assisted extraction to isolate polyphenols from Pomelo (Citrus maxima (Burm.) Merr.) and found that the extraction process had a certain effect on the antioxidant activity of polyphenols. When the concentration of ethanol was $60 \%$, the microwave power was $300 \mathrm{~W}$, the microwave-assisted time was $2 \mathrm{~min}$, and the solid-liquid ratio was 1:30, the highest content of polyphenols $(2.46 \mathrm{~g} \mathrm{GAE} / \mathrm{L})$ was obtained and the greatest antioxidant activity was detected (1325.85 mol TE/L). Yu et al. [66] used microwave heating (700 W for $20 \mathrm{~min}$ ) and high-temperature air heating $\left(120^{\circ} \mathrm{C}\right.$ for $\left.30 \mathrm{~min}\right)$ to extract polyphenols (lysergic acid, cinnamic acid, ferulic acid) from Asparagus. This method enables the extraction of new compounds that improve the anti-tyrosinase ability of asparagus and facilitate the application of polyphenols in food preservation and dietary pigmentation disorders adjuvant therapy. Bewal et al. [67] used multicomponent analysis microwave-assisted conditions to extract polyphenols from Berberis with optimal extraction conditions of $1 \mathrm{~g}$ of sample extracted through $70 \mathrm{~mL}$ of a solution $(100 \%$ methanol $\mathrm{pH} 2.0)$, provided microwave power of $598 \mathrm{~W}$ for $2 \mathrm{~min}$ of irradiation time. This method was also used to quantify the polyphenols in B. jaeschkeana and B. asiatica, and it was demonstrated to be a faster, more efficient, and greener extraction approach of polyphenols. Othman et al. [68] extracted polyphenolic substances from Clinacanthus nutans Lindau (C. nutans) by solvent-free microwave extraction under vacuum conditions and atmospheric pressure, this method is an effective and green technique that overcomes the limitations of high organic solvent usage, time-consuming and low extraction rate. Petrotos et al. [69] investigated the vacuum microwave-assisted extraction of polyphenols and flavonoids using pomegranate pomace as raw material and optimized it to be used industrially. The optimal conditions for surface extraction of total polyphenols and total flavonoids were: microwave power of $4961.07 \mathrm{~W}$, water to pomace ratio of 29.9, extraction time of $119.53 \mathrm{~min}$, and microwave power of $4147.76 \mathrm{~W}$, water to pomace ratio of 19.32, extraction time of $63.32 \mathrm{~min}$, respectively. The optimum conditions for total polyphenols and total flavonoids at the economic level were microwave power of $2048.62 \mathrm{~W}$, water to pomace ratio of 23.11, extraction time of $15.04 \mathrm{~min}$, and microwave power of $4008.62 \mathrm{~W}$, water to pomace ratio of 18.08 , extraction time of $15.29 \mathrm{~min}$, respectively. Accordingly, microwave extraction technology can be successfully produced industrially with high economic efficiency. However, the use of microwaves can make the local temperature rise shortly, and the necessary protective measures should be provided for the operator during operation.

\subsection{Enzymatic Extraction Method}

The enzymatic extraction method uses specific biological enzymes that selectively disrupt the plant cell walls and facilitate the diffusion of polyphenols from plant cells to the solvent. Bio-enzyme extraction is considered a green technology with the advantages of higher polyphenol dissolution rate, which make it suitable for industrial production. Four proteases (alkaline protease, neutral protease, pepsin, and papain) and three carbohydrases (cellulase, pectinase, and xylanase) are commonly used. 
Saad et al. [70] used enzyme-assisted extraction to recover lipophilic and hydrophilic phytochemicals (e.g., PUFAs, tocols, phytosterols, and ETs) from Raspberry (Rubus idaeus L.) pomace press-cak, the optimal extraction conditions for high extraction rates and cost savings were hydrolysis at $\mathrm{pH} 9,60^{\circ} \mathrm{C}$, and 1.2 units of alkaline protease inhibitor for $2 \mathrm{~h}$ per $100 \mathrm{~g}$ of pomace press-cake. The extraction rates of polyphenols and antioxidants were increased by $48 \%$ and $25 \%$, respectively, compared to the organic solvent method. Shankar et al. [71] compared the effectiveness of polyphenol extraction between the use of lignocellulose hydrolase secreted by Sphingobacterium sp. ksn and the traditional solvent (ethanol, methanol) methods. It was found that the enzymic extraction method yielded higher contents of polyphenols, flavonoids, and tannins compared to the solvent-assisted method. Domínguez-Rodríguez et al. [72] used an enzyme-assisted extraction of non-extractable polyphenols from sweet cherry (Prunus avium L.) residues. The optimal extraction time was $40 \mathrm{~min}$ for Depol and Promod and $18.4 \mathrm{~min}$ for Pectinase enzyme at $70^{\circ} \mathrm{C}$ and $\mathrm{pH}$ of 10 while the optimum enzymic concentration was $140 \mu \mathrm{L}$ of Promod $/ \mathrm{g}, 90 \mu \mathrm{L}$ of Depol/g, and $2 \mu \mathrm{L}$ of Pectinase/g of the sample. Under these conditions, the obtained phenolic content was higher, and the biological activity of isolated proanthocyanidins was also higher than those from the alkaline hydrolysis and acid hydrolysis methods. In summary, enzymatic extraction can increase the yield of active ingredients; reduce the time and energy consumption of the extraction process; and because enzymatic extraction can be carried out at room temperature and under non-organic solvents, the products obtained are of higher purity, stability, and activity, and are free from contamination. Therefore, the enzymatic method will be more and more widely used in the extraction of plant polyphenols.

\subsection{Resin Adsorption Extraction Method}

Macroporous adsorbent resin is a kind of organic polymer adsorbent that is generated from the polymerization reaction of crosslinker, polymeric monomer, dispersant, and other additives and is able to extract plant polyphenols due to its porous structure and selective adsorption function. The extraction of plant polyphenols by the macroporous adsorbent resin method has been widely used because of its high stability, good selectivity, high adsorption capacity, long service life, simple operation, not affected by the presence of inorganic substances, mild resolution conditions, and easy to constitute a closed circuit.

Bretag et al. [73] investigated the adsorption of quercetin-3-O-rutinoside (rutin) on Amberlite ${ }^{\circledR}$ XAD 16HP. This method allows for the isolation or separation of individual polyphenols or the enrichment of specific polyphenol subclasses from crude phenolic extracts via adjusting the optimal adsorption conditions for individual compounds. Kammerer et al. [74] used food-grade acrylic adsorbents for the separation and purification of phenolic compounds from crude plant extracts and found that grading of the extracts based on the hydrophilicity of the phenolics was possible and resin adsorption properties were required to improve the recovery and fractionation potential of the phenolic compounds isolated from plant material., Fu et al. [75] used a macroporous adsorption resin to adsorb and purify apple polyphenols under the following optimal adsorption conditions: HPD-100 MR, $2.5 \mathrm{BV} / \mathrm{hr}$ flow rate, $0.44 \mathrm{Abs}$ adsorption concentration, and $\mathrm{pH}$ 2.13. Under these conditions, the polyphenol adsorption rate reached $95.27 \%$. In general, although the resin sorptive extraction method has the advantages of high stability and high sorption capacity, the high cost of the resin market makes this method not suitable for large-scale extraction.

\subsection{Pulsed Electric Field (PEF) Method}

The extraction of plant polyphenols by the PEF is a non-thermal extraction technique, which can effectively promote the extraction of plant polyphenols by expanding the pore size of the plant cell wall and rupture using a high voltage PEF during the extraction process. With the advantages of short time

consumption, low energy consumption, minor temperature rise, and invariance of extracted plant 
polyphenols, the application of the high voltage PEF method in plant polyphenol extraction has attracted broad attention from scholars worldwide. The schematic of the circulation system for pulsed electric field treatment is shown in Fig. 4 [76].

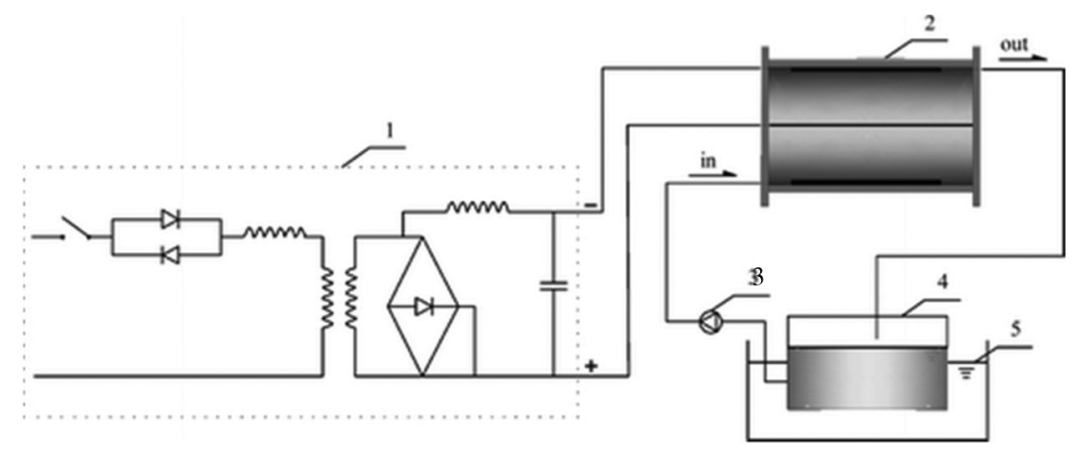

Figure 4: Schematic of the circulation system for pulsed electric field treatment: (1) pulsed power supply, (2) treatment chamber, (3) water pump, (4) reservoir, (5) cooling water bath

Liu et al. [77] used PEF instead of the conventional thermodynamic hydration process before phenol extraction. It was found that PEF pretreatment could be used to replace the time- and energy-intensive drying process. The application of an external electric field caused the formation of a large number of pores and protrusions on the surface of tea tissues, and this improved permeability and facilitated the release of phenolics, thus increasing the extraction efficiency. Compared with vacuum drying, PEF treatment increased the extraction rate by approximately two-fold without significant changes in the phenolic composition. Barbosa-Pereira et al. [78] used PEF to treat Cocoa Bean Shell and Coffee Silverskin and obtained higher ( 20\%) polyphenol recoveries. Carrots were subjected to different electric field strengths $\left(0.8,2\right.$, and $\left.3.5 \mathrm{kV} \cdot \mathrm{cm}^{-1}\right)$ and the number of pulses $(5,12$, and 30$)$. The largest increases in phenolic content were produced $24 \mathrm{~h}$ after applying 30 pulses of $0.8 \mathrm{kV} \cdot \mathrm{cm}^{-1}(40.1 \%)$ and 5 pulses of $3.5 \mathrm{kV} \cdot \mathrm{cm}^{-1}(39.5 \%)$. And PEF treatment doesn't affect the color of the radish [79]. Maza et al. [80] found the highest amount of total anthocyanin, total polyphenols, tannin content, and color intensity were generated in PEF-treated grapes. PEF helps to extract some precursors that are positive for aroma. These studies were conducted under conditions close to industrial-scale requirements and may encourage wineries to adopt PEF technology. Comuzzo et al. [81] also found an increase in anthocyanin and tannin content in wines after PEF treatment. PEF is a green technology that can improve phenol extraction from branched starch of blueberry pomace [82] and can increase the concentration of phenolic compounds in olive pomace [83]. Ricci et al. [84] found that a mild PEF can also be applied to reduce the accumulation of bioactive compounds in plants to obtain commodities with health-promoting properties. López-Gámez et al. [85] found that the timing of PEF treatment of postharvest carrots affected their compound content, respiration rate, volatile organic compound production, and enzyme activity, with a significant 24 h posttreatment regime, accompanied by a significant increase in total phenolic content $(80.2 \%)$.

There is still a lot of research work to be done on the PEF method. For example, the development of correct mathematical models for different systems and materials; the scientific interpretation and treatment of the interaction effects of various influencing factors, etc. Moreover, the PEF method has the potential to complement or replace the traditional natural product extraction methods, which span across multiple disciplines, and should be further optimized, tested on a larger scale, and applied to production. 


\subsection{Pressurized Liquid Extraction (PLE)}

PLE is a new extraction technique that uses organic solvents at high pressures (10.3-20.6 MPa) and temperatures $\left(50-200^{\circ} \mathrm{C}\right)$ above their normal boiling point. PLE has the following advantages over other solvent extraction techniques: the extraction process is automated, the extraction time is greatly reduced, the amount of extraction solvent used is significantly reduced, the extraction process is carried out in a closed system to reduce solvent volatilization and harm to humans, and the pollution of the environment is reduced.

Feuereisen et al. [86] used response surface methodology to investigate the effect of pressurized liquid extraction (PLE) parameters on the recovery of phenolic compounds (anthocyanins, biflavones) from Brazilian pepper (Schinus terebinthifolius Raddi) fruit. The effects of the multivariate optimization confirmed higher yields of phenolic compounds in the peel/drupe at $100 / 75^{\circ} \mathrm{C}, 10 / 10 \mathrm{~min}, 54.5 / 54.2 \%$ ethanol, and $5 / 0.03 \%$ acetic acid. It indicates that the supercritical extraction technique can higher extract the phenolic compounds from rosin. Corazza et al. [87] observed pressurized ethanol to be of interesting applicability in the coaching of bioactive compounds. However, this method requires precise prerequisites to ensure that these compounds have suitable antioxidant activity. PLE can select the extraction conditions according to the available experimental data, and all mature methods of solvent extraction can be used in the PLE method, saving the manpower and material resources of the analysis. Meanwhile, PLE can be used to select the extraction conditions according to the available experimental data. In addition, the influence of the matrix on PLE extraction is less than that of other solvent extraction methods, and the same extraction conditions can be used for different matrixes of PLE. In brief, the use of PLE extraction technology in the pretreatment of biological samples has shown good prospects for application and tends to gradually replace the traditional solvent extraction method. There are now instrument manufacturers in China developing pressurized liquid extraction instruments, which will facilitate the popularization of this technique and will reduce the workload of analysts and speed up analysis.

\subsection{High Hydrostatic Pressure Extraction (HHPE)}

HHPE is a typical non-thermal processing technology that has great potential for the production and processing of high-quality fruit and vegetable products due to its ability to effectively retain nutrients and heat-sensitive active ingredients (such as vitamins and plant polyphenols) in the food, as well as to preserve the multiple functional activities of the active ingredients in fruits and vegetables.

A study by Queiroz et al. [88] evaluated the effects of HHPE and storage $\left(2\right.$ or $\left.27^{\circ} \mathrm{C} / 24 \mathrm{~h}\right)$ on the phytochemicals of fresh-cut cashew apples. Under $250 \mathrm{MPa}$ treatment, damage and HHPE treatment resulted in the destruction of enzymes and phenolic substrates released from the cellular compartment and the start of fruit browning. Thus, at $250 \mathrm{MPa}$ and $27^{\circ} \mathrm{C}$, fresh-cut cashew apples lost all color parameters, had altered polyphenols, and reduced antioxidant capacity. There was less damage to the bioactive substances and antioxidant capacity of fresh-cut cashew apples processed at $400 \mathrm{MPa}$ and then at $2^{\circ} \mathrm{C}$. Grassino et al. [89] found that by reducing the extraction time of HHPE, two valuable functional components, pectin, and polyphenols, could be efficiently produced while reducing the environmental pollution by reducing the peel waste generated by the tomato canning industry. Compared to conventional thermal processing, HHPE treatment has a better retention effect on the phenolic content and antioxidant and anti-inflammatory activities of fruits and vegetables, mainly because high pressure disrupts the cell membrane structure and promotes the release of bioactive substances, and high-pressure treatment also causes structural changes in anthocyanins and phenolic acids, resulting in the formation of new compounds. However, there are still many scientific questions about how high-pressure conditions affect the interaction between phenolic compounds and macromolecules, and how they affect the bioavailability of phenolic compounds. 
Although the advantages of HHPE non-thermal processing technology in fruit and vegetable processing are obvious, it is still limited in two ways: firstly, the theory of pressure kinetics leading to microbial and enzyme inactivation is not well developed to ensure that high-pressure processes can replace conventional heating processes; secondly, the development of continuous pressure processing machinery for food is still a challenge, with high investment and maintenance costs for equipment. Therefore, the development and promotion of HHPE non-thermal processing technology still require a large amount of scientific theory and equipment technology as support.

\subsection{Multi-Method Combination}

To improve the extraction rate of natural products, multiple extraction approaches are frequently used in combination. Mushtaq et al. [90] extracted black tea waste hydrolyzed by different enzymes using supercritical carbon dioxide and ethanol as co-solvents $\left(\mathrm{SC}-\mathrm{CO}_{2}+\mathrm{EtOH}\right)$. Compared with conventional solvent extraction (ethanol: $\mathrm{H}_{2} \mathrm{O}$ of 80:20, w), it was found that the combined extraction yielded cleaner polyphenol extracts and enriched polyphenol content than the conventional method. Kantar et al. [91] used high voltage electrical discharges (HVED) combined with enzymatic hydrolysis for the extraction of orange peel polyphenols. The highest extraction rate of polyphenols $(0.7 \mathrm{~g} / 100 \mathrm{~g} \mathrm{DM})$ was achieved when HVED energy input was $222 \mathrm{~kJ} / \mathrm{kg}$ and Viscozyme ${ }^{\circledR} \mathrm{L}$ concentration reached $12 \mathrm{FBGU}$. Borda-Yepes et al. [92] found that the combination of microwave and IR drying increased the extraction efficiency of polyphenols from blueberry (mortiño) leaves (Vaccinium meridionale-Swartz). Fu et al. [93] developed a novel method that includes microwave and enzyme-assisted two-phase extraction. The recovery of total phenols reached $95.35 \%$ at $28 \%(\mathrm{~W} / \mathrm{W})$ with the ethanol $/ 20 \%(\mathrm{~W} / \mathrm{W})$ ammonium sulfate, $0.45 \mathrm{U} / \mathrm{g}$ enzyme concentration, enzymatic digestion time of $120 \mathrm{~s}$, and microwave power of $270 \mathrm{~W}$. TrujilloMayol et al. [94] used the microwave in combination with ultrasound to maximize the extraction of phenolics from the avocado peel. This method effectively improved the phytochemical and biological properties of the hydroethanolic extracts from avocado peel and reduced the consumption of energy and raw materials.

There are more studies on the combination of ultrasonic and enzymatic methods. Nag et al. [95] used an ultrasonic-assisted enzymatic method to extract polyphenols from pomegranate peel $(P$. granatum L.). The optimal extraction conditions for polyphenols (19.77 mg GAE/g) were ultrasonic time 41.45 min, enzyme concentration $1.32 \mathrm{~mL} / 100 \mathrm{~mL}$, incubation time $1.82 \mathrm{~h}$, and incubation temperature $44.85^{\circ} \mathrm{C}$. Nishad et al. [96] used this method to extract the total phenolic substances of citrus. The optimal extraction conditions assisted by ultrasound were: wave amplitude $70.89 \%$, liquid to solid ratio $40 \mathrm{~mL} / \mathrm{g}$, and extraction time $35 \mathrm{~min}$. The optimal extraction conditions assisted by enzyme were: enzyme concentration $30.94 \mathrm{~mL} / \mathrm{g}$, liquid to solid ratio $30.94 \mathrm{~mL} / \mathrm{g}$, and extraction time $4.87 \mathrm{~h}$. Balasubramaniam et al. [97] used ultrasound combined with xylanase to extract Finger millet (Eleusine coracana) polyphenols and their polyphenol yield was increased by 2.3-fold. Olawuyi et al. [98] found that combined ultrasound-enzyme treatment shortened the processing time of plum (Prunus salicina L.) juice (up to 4-fold) and significantly increased the yield, active substance, and antioxidant capacity of orange juice samples, thus validating the superiority of combined treatment over single treatment.

In order to overall review the different technologies for extraction of polyphenol, the main extraction results, advantages and deficiencies of solvent extraction, supercritical fluid extraction, ultrasonic extraction, microwave extraction, enzymatic extraction, resin adsorption extraction, PEF method are summarized in Table 2. 
Table 2: A summary of the extraction method of polyphenols from different plants and their advantages and disadvantages

\begin{tabular}{|c|c|c|c|c|c|}
\hline Method & Plants & Polyphenols content & Advantages & Deficiencies & References \\
\hline \multirow[t]{2}{*}{$\begin{array}{l}\text { Solvent } \\
\text { extraction }\end{array}$} & $\begin{array}{l}\text { Aronia } \\
\text { melanocarpa }\end{array}$ & $\begin{array}{l}27.8 \mathrm{mg} / \mathrm{g}: 50 \% \text { ethanol; particle } \\
\text { size- } 0.75 \mathrm{~mm} \text {; solid-liquid ratio- } \\
1: 20(\mathrm{~m} / \mathrm{V})\end{array}$ & \multirow[t]{2}{*}{$\begin{array}{l}\text { Simple procedures, } \\
\text { low cost and high } \\
\text { isolation purity }\end{array}$} & \multirow[t]{2}{*}{$\begin{array}{l}\text { Extraction rate is } \\
\text { relatively low }\end{array}$} & {$[43]$} \\
\hline & $\begin{array}{l}\text { chicorium } \\
\text { intybus }\end{array}$ & $3 \mathrm{~g} / \mathrm{kg}:$ subcritical water & & & {$[47]$} \\
\hline \multirow[t]{4}{*}{$\begin{array}{l}\text { Supercritical } \\
\text { fluid } \\
\text { extraction }\end{array}$} & Avena sativa $\mathrm{L}$. & $\begin{array}{l}\text { p-Coumaric and ferulic acid } \\
\text { ( } 449 \text { and } 964 \mu \mathrm{g} / \mathrm{g} \text { of oat): } \\
\text { Ethanol }(80 \% \mathrm{v} / \mathrm{v})-\text {-co-solvent; } \\
30-40 \mathrm{MPa} ; 50-60^{\circ} \mathrm{C}\end{array}$ & \multirow[t]{4}{*}{$\begin{array}{l}\text { Efficient and } \\
\text { environmentally } \\
\text { friendly }\end{array}$} & \multirow[t]{4}{*}{$\begin{array}{l}\text { High cost not suitable } \\
\text { for industrial }\end{array}$} & {$[54]$} \\
\hline & $\begin{array}{l}\text { Callisia } \\
\text { fragrans }\end{array}$ & $\begin{array}{l}87.42 \mathrm{mg} \mathrm{GAE} / \mathrm{g}: 14 \% \text { ethanol; } \\
\mathrm{CO}_{2} \text { flow rate- } 20 \mathrm{~g} / \mathrm{min} ; 45^{\circ} \mathrm{C} ; \\
\text { pressure- } 200 \mathrm{bar}\end{array}$ & & & {$[57]$} \\
\hline & Lupinus luteus & $\begin{array}{l}14.56 \mathrm{mg} / \mathrm{g}: 73^{\circ} \mathrm{C}, 147 \mathrm{bar}, \\
16.1 \% \text { co-solvent }\end{array}$ & & & {$[55]$} \\
\hline & $\begin{array}{l}\text { Mangifera } \\
\text { indica } \mathrm{L} .\end{array}$ & $\begin{array}{l}71.47 \mathrm{~g} / 100 \mathrm{~g} \text { dry extract: } \mathrm{CO}_{2}+ \\
6 \% \text { ethanol under } 300 \mathrm{bar} \text { and } \\
45^{\circ} \mathrm{C} \text {, at a fast depressurizing rate } \\
\text { of } 5 \mathrm{bar} / \mathrm{min} \text { during } 24 \mathrm{~h}\end{array}$ & & & [99] \\
\hline $\begin{array}{l}\text { Ultrasonic } \\
\text { extraction }\end{array}$ & $\begin{array}{l}\text { Brassica } \\
\text { napus L. }\end{array}$ & $\begin{array}{l}12.64 \mathrm{mg} / \mathrm{g} \text { : material-to-liquid } \\
\text { ratio of } 1: 30(\mathrm{~g} / \mathrm{mL}) \text {, ultrasonic } \\
\text { extraction time of } 30 \mathrm{~min} \text {, } \\
\text { extraction power of } 240 \mathrm{~W} \text {, and } \\
\text { nitrogen flow rate of } 5 \mathrm{~L} / \mathrm{min}\end{array}$ & $\begin{array}{l}\text { High yield, short time, } \\
\text { low energy } \\
\text { consumption, structure } \\
\text { is not easily damaged }\end{array}$ & Lower purity & {$[60]$} \\
\hline \multirow[t]{2}{*}{$\begin{array}{l}\text { Microwave } \\
\text { extraction }\end{array}$} & $\begin{array}{l}\text { Citrus maxima } \\
\text { (Burm.) Merr. }\end{array}$ & $\begin{array}{l}2.46 \mathrm{~g} \text { GAE} / \mathrm{L}: 60 \% \text { ethanol, the } \\
\text { microwave power was } 300 \mathrm{~W} \text {, the } \\
\text { microwave-assisted time was } \\
2 \mathrm{~min} \text {, and the solid-liquid ratio } \\
\text { was } 1: 30\end{array}$ & \multirow[t]{2}{*}{$\begin{array}{l}\text { High efficiency, cheap } \\
\text { and environmentally } \\
\text { friendly }\end{array}$} & \multirow[t]{2}{*}{$\begin{array}{l}\text { Pay attention to } \\
\text { protection during } \\
\text { operation }\end{array}$} & {$[65]$} \\
\hline & $\begin{array}{l}\text { Clinacanthus } \\
\text { nutans Lindau } \\
\text { (C. nutans) }\end{array}$ & $\begin{array}{l}24.08 \mathrm{mg} \text { GAE} / \mathrm{g} \mathrm{DW} \text { : energy } \\
\text { density of } 0.073 \mathrm{~W} / \mathrm{mL}, 6 \mathrm{~mL} / \mathrm{q} \\
\text { of } \mathrm{S} / \mathrm{F} \text { ratio and } 5 \mathrm{~min}\end{array}$ & & & {$[68]$} \\
\hline \multirow[t]{2}{*}{$\begin{array}{l}\text { Enzymatic } \\
\text { extraction }\end{array}$} & $\begin{array}{l}\text { Rubus } \\
\text { idaeus L. }\end{array}$ & $\begin{array}{l}2.5 \mathrm{~g} / 100 \mathrm{~g} \text { of dried raspberry } \\
\text { pomace: } \mathrm{pH} 9,60^{\circ} \mathrm{C} \text {, and } \\
1.2 \text { units of alkaline protease } \\
\text { inhibitor for } 2 \mathrm{~h} \text { per } 100 \mathrm{~g} \text { of } \mathrm{PPC}\end{array}$ & \multirow{2}{*}{$\begin{array}{l}\text { Green, lower cost and } \\
\text { higher dissolution rate, } \\
\text { the reaction conditions } \\
\text { are mild, the product } \\
\text { purity, stability, } \\
\text { activity are high, } \\
\text { suitable for industrial } \\
\text { production }\end{array}$} & \multirow{2}{*}{$\begin{array}{l}\text { The product is easy to } \\
\text { be destroyed, the loss } \\
\text { is large, the process } \\
\text { operation control is } \\
\text { strict }\end{array}$} & {$[70]$} \\
\hline & $\begin{array}{l}\text { Prunus } \\
\text { avium L. }\end{array}$ & $\begin{array}{l}70^{\circ} \mathrm{C} \text { and } \mathrm{pH} \text { of } 10 \\
1.33 \mathrm{mg} \mathrm{GAE} / \mathrm{g} \text { of extraction } \\
\text { residue: } 40 \mathrm{~min} \text { for } 90 \mu \mathrm{L} \text { of } \\
\text { Depol/g; } \\
1.75 \mathrm{mg} \mathrm{GAE} / \mathrm{g} \text { of extraction } \\
\text { residue: } 40 \mathrm{~min} \text { for } 140 \mu \mathrm{L} \text { of } \\
\text { Promod/g; } \\
1.11 \mathrm{mg} \mathrm{GAE} / \mathrm{g} \text { of extraction } \\
\text { residue: } 18.4 \text { min for } 2 \mu \mathrm{L} \text { of } \\
\text { Pectinase } / \mathrm{g} \text {; }\end{array}$ & & & {$[72]$} \\
\hline
\end{tabular}


JRM, 2022, vol.10, no.6

Table 2 (continued)

\begin{tabular}{|c|c|c|c|c|c|}
\hline Method & Plants & Polyphenols content & Advantages & Deficiencies & References \\
\hline $\begin{array}{l}\text { Resin } \\
\text { adsorption } \\
\text { extraction }\end{array}$ & $\begin{array}{l}\text { Malus } \\
\text { domestica }\end{array}$ & $\begin{array}{l}\text { Adsorption rate reached } 95.27 \% \text { : } \\
\text { HPD- } 100 \mathrm{MR}, 2.5 \mathrm{BV} / \mathrm{hr} \text { flow } \\
\text { rate, } 0.44 \mathrm{Abs} \text { adsorption } \\
\text { concentration, and } \mathrm{pH} 2.13\end{array}$ & $\begin{array}{l}\text { High stability, good } \\
\text { selectivity, high } \\
\text { adsorption capacity, } \\
\text { long service life, } \\
\text { simple operation, not } \\
\text { affected by the } \\
\text { presence of inorganic } \\
\text { substances, mild } \\
\text { resolution conditions, } \\
\text { easy to constitute a } \\
\text { closed circuit }\end{array}$ & $\begin{array}{l}\text { The resin market is } \\
\text { expensive, high cost, } \\
\text { not suitable for large- } \\
\text { scale extraction }\end{array}$ & {$[75]$} \\
\hline \multirow[t]{3}{*}{$\begin{array}{l}\text { Pulsed } \\
\text { electric field } \\
\text { method }\end{array}$} & $\begin{array}{l}\text { Camellia } \\
\text { sinensis }\end{array}$ & $\begin{array}{l}398 \mathrm{mg} / \mathrm{L} \text { tea polyphenols in } 2 \mathrm{~h} \text { : } \\
\text { a field strength of } 1.00 \mathrm{kV} / \mathrm{cm} \text { and } \\
100 \text { pulses, the energy } \\
\text { consumption and temperature } \\
\text { elevation were } 22 \mathrm{~kJ} / \mathrm{kg} \text { and } \\
1.5^{\circ} \mathrm{C}\end{array}$ & \multirow{3}{*}{$\begin{array}{l}\text { Short time } \\
\text { consumption, low } \\
\text { energy consumption, } \\
\text { small temperature rise, } \\
\text { and invariance }\end{array}$} & \multirow[t]{3}{*}{$\begin{array}{l}\text { High requirement for } \\
\text { the instrument }\end{array}$} & {$[77]$} \\
\hline & $\begin{array}{l}\text { Daucus carota } \\
\text { cv. Nantes }\end{array}$ & $\begin{array}{l}\text { The largest increases in phenolic } \\
\text { content were produced } 24 \mathrm{~h} \text { after } \\
\text { applying } 30 \text { pulses of } \\
0.8 \mathrm{kV} \cdot \mathrm{cm}^{-1}(40.1 \%) \text { and } \\
5 \text { pulses of } 3.5 \mathrm{kV} \cdot \mathrm{cm}^{-1}(39.5 \%)\end{array}$ & & & [79] \\
\hline & Vaccinium Spp & $\begin{array}{l}\text { Anthocyanin }(1757.32 \mu \mathrm{g} / \mathrm{g} \text { of } \\
\mathrm{dw}) \text { and flavanol }(297.86 \mathrm{ug} / \mathrm{g} \text { of } \\
\mathrm{dw}) \text { yields were obtained in the } \\
\text { methanol-based solvent, while } \\
\text { the highest phenolic acid } \\
(625.47 \mathrm{ug} / \mathrm{g} \text { of } \mathrm{dw}) \text { and flavonol } \\
(157.54 \mathrm{ug} / \mathrm{g} \text { of } \mathrm{dw}): \text { in the } \\
\text { ethanol-based solvent after } \\
100 \text { pulses and } 20 \mathrm{kV} \cdot \mathrm{cm}^{-1}\end{array}$ & & & [82] \\
\hline $\begin{array}{l}\text { Pressurized } \\
\text { liquid } \\
\text { extraction }\end{array}$ & $\begin{array}{l}\text { Pistacia } \\
\text { vera } \mathrm{L} .\end{array}$ & $\begin{array}{l}\text { The optimal conditions for the } \\
\text { drupe extraction were } 54.2 \% \\
\text { ethanol, } 0.03 \% \text { acid and } 10 \mathrm{~min} \\
\text { static time (desirability }=0.59 \text { ). } \\
\text { For the drupes, up to three } \\
\text { extraction cycles were considered } \\
\text { appropriate since two cycles } \\
\text { resulted in a vield of biflavonoid } \\
4 \text { of } 78.6 \% \text { referred to a total } \\
\text { vield obtained after } 3 \text { cycles }\end{array}$ & $\begin{array}{l}\text { Automation, short } \\
\text { time, low solvent } \\
\text { consumption, reduced } \\
\text { solvent volatilisation } \\
\text { and environmental } \\
\text { pollution }\end{array}$ & $\begin{array}{l}\text { High requirement for } \\
\text { the instrument }\end{array}$ & [86] \\
\hline \multirow[t]{2}{*}{$\begin{array}{l}\text { High } \\
\text { hydrostatic } \\
\text { pressure } \\
\text { extraction }\end{array}$} & $\begin{array}{l}\text { Anacardium } \\
\text { occidentale L. }\end{array}$ & $\begin{array}{l}\text { The contents of soluble and } \\
\text { hydrolysable phenolic } \\
\text { compounds in fresh-cut cashew } \\
\text { apple were } 279.13 \text { and } 355.28 \mathrm{mg} \\
\text { EAG/100 g FW }\end{array}$ & \multirow{2}{*}{$\begin{array}{l}\text { It can effectively retain } \\
\text { nutrients and heat- } \\
\text { sensitive active } \\
\text { ingredients }\end{array}$} & \multirow{2}{*}{$\begin{array}{l}\text { The theory of pressure } \\
\text { kinetics leading to } \\
\text { microbial and enzyme } \\
\text { inactivation is not } \\
\text { well; high investment } \\
\text { and maintenance costs } \\
\text { for equipment }\end{array}$} & [88] \\
\hline & $\begin{array}{l}\text { Solanum } \\
\text { lycopersicum }\end{array}$ & $\begin{array}{l}\text { Polyphenol content of } \\
3643.9 \mathrm{mg} / 100 \mathrm{~g} \text {; HHPE } \\
\text { enhanced pectin recovery by } 15 \% \\
\text { after } 45 \mathrm{~min} \text { of recycling, in } \\
\text { comparison with the conventional } \\
\text { extraction for } 180 \mathrm{~min}\end{array}$ & & & [89] \\
\hline
\end{tabular}


Table 2 (continued)

\begin{tabular}{|c|c|c|c|c|c|}
\hline Method & Plants & Polyphenols content & Advantages & Deficiencies & References \\
\hline \multirow[t]{5}{*}{$\begin{array}{l}\text { Multi- } \\
\text { method } \\
\text { combination }\end{array}$} & $\begin{array}{l}\text { Camellia } \\
\text { sinensis }\end{array}$ & $\begin{array}{l}\text { Offering } 5 \text {-fold higher extract } \\
\text { yield }(\mathrm{g} / 100 \mathrm{~g}) \text { : supercritical } \\
\text { carbon dioxide and ethanol as co- } \\
\text { solvents }\end{array}$ & \multirow{5}{*}{$\begin{array}{l}\text { Maximize the } \\
\text { extraction of } \\
\text { phenolics, high } \\
\text { efficiency and } \\
\text { reducing the } \\
\text { consumption of energy } \\
\text { and raw materials }\end{array}$} & \multirow[t]{5}{*}{$\begin{array}{l}\text { Cumbersome } \\
\text { processes }\end{array}$} & [90] \\
\hline & $\begin{array}{l}\text { Citrus } \\
\text { reticulata } \\
\text { Blanco }\end{array}$ & $\begin{array}{l}0.7 \mathrm{~g} / 100 \mathrm{~g} \text { DM: HVED energy- } \\
222 \mathrm{~kJ} / \mathrm{kg} \text {, Viscozyme }{ }^{\circledR} \mathrm{L} \\
\text { concentration-12 FBGU/ HVED }\end{array}$ & & & [91] \\
\hline & $\begin{array}{l}\text { Tagetes } \\
\text { erecta } \mathrm{L} .\end{array}$ & $\begin{array}{l}\text { Total phenols reached } 95.35 \% \text { : } \\
28 \%(\mathrm{~W} / \mathrm{W}) \text {, ethanol } / 20 \%(\mathrm{~W} / \mathrm{W}) \\
\text { ammonium sulfate, } 0.45 \mathrm{U} / \mathrm{g} \\
\text { enzyme concentration, enzymatic } \\
\text { digestion time of } 120 \mathrm{~s} \text {, and } \\
\text { microwave power of } 270 \mathrm{~W}\end{array}$ & & & [93] \\
\hline & $\begin{array}{l}\text { Punica } \\
\text { granatum L. }\end{array}$ & $\begin{array}{l}19.77 \mathrm{mg} \text { GAE/g: ultrasonic time } \\
41.45 \mathrm{~min} \text {, enzyme concentration } \\
1.32 \mathrm{~mL} / 100 \mathrm{~mL} \text {, incubation time } \\
\text { of } 1.82 \mathrm{~h} \text {, and incubation } \\
\text { temperature of } 44.85^{\circ} \mathrm{C}\end{array}$ & & & [95] \\
\hline & $\begin{array}{l}\text { Citrus sinensis } \\
\text { (cv. Malta) }\end{array}$ & $\begin{array}{l}1590 \mathrm{mg} \mathrm{GAE} / 100 \mathrm{~g} \text { : wave } \\
\text { amplitude } 70.89 \% \text {, liquid to solid } \\
\text { ratio } 40 \mathrm{~mL} / \mathrm{g} \text {, and extraction time } \\
35 \mathrm{~min} \text {. The optimal extraction } \\
\text { conditions assisted by enzyme } \\
\text { were: enzyme concentration } \\
30.94 \mathrm{~mL} / \mathrm{g} \text {, liquid to solid ratio } \\
30.94 \mathrm{~mL} / \mathrm{g} \text {, and extraction time } \\
4.87 \mathrm{~h}\end{array}$ & & & {$[96]$} \\
\hline
\end{tabular}

\section{Conclusion and Prospects}

The used extraction technologies for the isolation of polyphenol not only possess advantages but also have some challenges. For the solvent extraction method, the yield of polyphenol can reach the requirement, but the long extraction time and high cost of solvent make it is not suitable for large-scale industrial production. Even a good great polyphenol yield can be obtained by ultrasound and supercritical extraction technology in a short extraction time, but the cost of carrying out the ultrasonic wave and high supercritical extraction conditions limits the wide application of these two extraction methods. For resin adsorption extraction, it has the advantage of a high extraction yield, purity of polyphenol, non-toxic and harmless, and no contamination for the environment, but the expensive resin is also not suitable for largescale extraction. The PEF method can effectively extract polyphenolic substances and has good prospects for development.

During the current period, the traditional solvent extraction method has been gradually replaced by new technologies such as microwave, flash extraction, and supercritical fluid extraction. However, more development for the new extraction technologies should be constantly updated. For these new technologies, it should be paid more attention to consider the limitations of equipment, practicability, and costs. Therefore, further development of low cost, high extraction rate, high purity, and green-safe polyphenol extraction technology will become the important direction of future research. 
Acknowledgement: Caoxing Huang proposed the idea. Yingying Hu and Bowen Yan wrote the manuscript. Zhefan Stephen Chen, Lei Wang and Wei Tang wrote and revised the manuscript.

Funding Statement: This work was sponsored by Natural Science Foundation of Jiangsu Province (BK20180772), National Natural Science Foundation of China (31800501), and Qing Lan Project.

Conflicts of Interest: The authors declare that they have no conflicts of interest to report regarding the present study.

\section{References}

1. Yahfoufi, N., Alsadi, N., Jambi, M., Matar, C. (2018). The immunomodulatory and anti-inflammatory role of polyphenols. Nutrients, 10(11), 1618. DOI 10.3390/nu10111618.

2. Ganesan, K., Xu, B. (2017). A critical review on polyphenols and health benefits of black soybeans. Nutrients, 9(5), 455. DOI 10.3390/nu9050455.

3. Fu, S., Wu, T., Wu, C. (2016). Plant polyphenols and their antioxidant and antibacterial mechanisms and their application in food. Food Industry, 37(6), 242-246.

4. Yan, B., Chen, Z. S., Hu, Y., Yong, Q. (2021). Insight in the recent application of polyphenols from biomass. Frontiers in Bioengineering and Biotechnology, 9, 268. DOI 10.3389/fbioe.2021.753898.

5. Poti, F., Santi, D., SpaggiarI, G., Zimetti, F., Zanotti, I. (2019). Polyphenol health effects on cardiovascular and neurodegenerative disorders: A review and meta-analysis. International Journal of Molecular Sciences, 20(2), 351. DOI 10.3390/ijms20020351.

6. Gandhi, G., Vasconcelos, A., Wu, D., Li, H., Can, R. (2020). Citrus flavonoids as promising phytochemicals targeting diabetes and related complications: A systematic review of in vitro and in vivo studies. Nutrients, 12(10), 1-32.

7. Boccellino, M., D'Angelo, S. (2020). Anti-obesity effects of polyphenol intake: Current status and future possibilities. International Journal of Molecular Science, 21(16), 1-2.

8. Tsao, R. (2010). Chemistry and biochemistry of dietary polyphenols. Nutrients, 2(12), 1231-1246.

9. Zheng, L., Yu, P., Zhang, Y., Wang, P., Yan, W. et al. (2021). Evaluating the bio-application of biomacromolecule of lignin-carbohydrate complexes (LCC) from wheat straw in bone metabolism via ROS scavenging. International Journal of Biological Macromolecules, 176, 13-25.

10. Zhou, X., Huang, L., Xu, Y., Yu, S. (2019). Mannonic acid and bio-ethanol production from konjac using a twostep bioprocess with candida shehatae and gluconobacter oxydans. Journal of Renewable Materials, 7(11), 79-88.

11. Li, B., Li, M., Wang, G., Wang, K., Jian, K. (2018). The antioxidant activity of pomegranate seed polyphenols in vitro. Science and Technology of Food Industry, 39(4), 17-20.

12. Su, H., Wei, J., Bi, Y., Hu, H., Wang, Z. (2017). Optimization of ultrasonic-assisted extraction of polyphenols from Chinese Seabuckthorn berries and composition analysis. Food and Fermentation Sciences \& Technology, 53(6), 34-41.

13. Zhang, X., Bei, Z., Qiao, Y. (2017). The anti-oxidation effects of polyphenols in Lyciumbarbarum L. fresh flower. Feed Industry, 38(18), 38-43.

14. Kitrytè, V., Povilaitis, D., Kraujalienè, V., Šulniūtè, V., Pukalskas, A. et al. (2017). Fractionation of sea buckthorn pomace and seeds into valuable components by using high pressure and enzyme-assisted extraction methods. LWTFood Science and Technology, 85(B), 534-538.

15. Xia, T., Zhao, C., Du, P. (2019). Research progress of polyphenols in food, extraction methods and detection techniques. Food and Fermentation Industries, 45(5), 231-238.

16. Wang, L., Lin, X., Zhang, J., Zhang, W., Hu, X. (2019). Extraction methods for the releasing of bound phenolics from Rubus idaeus L. leaves and seeds. Industrial Crops and Products, 135, 1-9.

17. Yun, J., Liao, W., Li, W., Gong, D., Qin, H. et al. (2021). Isolation the high antimicrobial ability lignin from bamboo kraft lignin by organosolv fractionation. Frontiers in Bioengineering and Biotechnology, 9, 683796. 
18. Both, S., Chemat, F., Strube, J. (2014). Extraction of polyphenols from black tea: Conventional and ultrasoundassisted extraction. Ultrasonics Sonochemistry, 21(3), 1030-1034.

19. Fang, L., Wu, H., Shi, Y., Tao, Y., Yong, Q. (2021). Preparation of lignin-based magnetic adsorbent from kraft lignin for adsorbing the Congo red. Frontiers in Bioengineering and Biotechnology, 9, 691528.

20. Wen, Y., Chen, H., Zhou, X., Deng, Q., Zhao, Y. (2015). Optimization of the microwave-assisted extraction and antioxidant activities of anthocyanins from blackberry using a response surface methodology. RSC Advances, 2015(5), 19686-19695.

21. Teng, H., Lee, W., Yong, H. (2013). Optimization of microwave-assisted extraction for anthocyanins, polyphenols, and antioxidants from raspberry (Rubus Coreanus Miq.) using response surface methodology. Journal of Separation Science, 36(18), 3107-3114. DOI 10.1002/jssc.201300303.

22. Timmermans, R., Nederhoff, A., Groot, M., Boekel, M., Mastwijk, H. (2016). Effect of electrical field strength applied by PEF processing and storage temperature on the outgrowth of yeasts and moulds naturally present in a fresh fruit smoothie. International Journal of Food Microbiology, 230(17), 21-30. DOI 10.1016/j. ijfoodmicro.2016.04.014.

23. Gironi, F., Piemonte, V. (2011). Temperature and solvent effects on polyphenol extraction process from chestnut tree wood. Chemical Engineering Research and Design, 89(7), 857-862. DOI 10.1016/j.cherd.2010.11.003.

24. Boadas-Vaello, P., Vela, J., Verdú, E. (2016). New pharmacological approaches using polyphenols on the physiopathology of neuropathic pain. Current Drug Targets, 18(2), 160-173. DOI 10.2174/1389450117666160527142423.

25. Nan, J., Andrea, D., Erich, G. (2016). Flavones: From biosynthesis to health benefits. Plants, 5(2), 27. DOI 10.3390/plants5020027.

26. Hostetler, G., Ralston, R., Schwartz, S. (2017). Flavones: Food sources, bioavailability, metabolism, and bioactivity. Advances in Nutrition: An International Review Journal, 8(3), 423-435. DOI 10.3945/an.116.012948.

27. Jakimiuk, K., Wink, M., Tomczyk, M. (2021). Flavonoids of the caryophyllaceae. Phytochemistry Reviews, 22, 148. DOI 10.1007/s11101-021-09755-3.

28. Wang, Y., Liu, X. J., Chen, J. B., Cao, J. P., Li, X. et al. (2021). Citrus flavonoids and their antioxidant evaluation. Critical Reviews in Food Science and Nutrition, 2, 1-22.

29. Kamiloglu, S., Tomas, M., Capanoglu, E. (2019). Dietary flavonols and O-glycosides. Singapore: Handbook of Dietary Phytochemicals.

30. Ishihara, H., Tohge, T., Viehöver, P., Fernie, A. R., Weisshaar, B. et al. (2016). Natural variation in flavonol accumulation in arabidopsis is determined by the flavonol glucosyltransferase BGLU6. Journal of Experimental Botany, 67(5), 1505-1517. DOI 10.1093/jxb/erv546.

31. Dludla, P., Nkambule, B., Jack, B., Mkandla, Z., Mutize, T. et al. (2019). Inflammation and oxidative stress in an obese state and the protective effects of gallic acid. Nutrients, 11(1), 23. DOI 10.3390/nu11010023.

32. Adriano, C., Marisa, A., Gabriela, B., Solange, G., Leonardo, P. et al. (2017). Phenolic acids and flavonoids of peanut by-products: Antioxidant capacity and antimicrobial effects. Food Chemistry, 237, 538-544. DOI 10.1016/j.foodchem.2017.05.046.

33. Hefni, M. E., Amann, L. S., Witthöft, C. M. (2019). A HPLC-UV method for the quantification of phenolic acids in cereals. Food Analytical Methods, 12(12), 2802-2812. DOI 10.1007/s12161-019-01637-x.

34. Haytowitz, D., Bhagwat, S. (2015). USDA database for the isoflavone content of selected foods, Release 2.1. DOI 10.15482/USDA.ADC/1324538.

35. Zhou, T. J., Meng, C. Z., He, P. L. (2019). Soy isoflavones and their effects on xenobiotic metabolism. Current Drug Metabolism, 20(1), 46-53. DOI 10.2174/1389200219666180427170213.

36. Mena, P., Bresciani, L., Brindani, N., Ludwig, I., Rio, D. (2019). Phenyl- $\gamma$-valerolactones and phenylvaleric acids, the main colonic metabolites of flavan-3-ols: Synthesis, analysis, bioavailability, and bioactivity. Natural Product Reports, 36(1), 714-752. DOI 10.1039/C8NP00062J.

37. Lee, Y., Yang, H., Hur, G., Yu, J., Park, S. et al. (2019). 5-(3',4'-Dihydroxyphenyl)- $\gamma$-valerolactone, a metabolite of procyanidins in cacao, suppresses MDI-induced adipogenesis by regulating cell cycle progression through direct inhibition of CDK2/cyclin O. Food \& Function, 10(5), 2958-2969. DOI 10.1039/C9FO00334G. 
38. Fayeulle, N., Vallverdu, Q., Meudec, E., Hue, C., Renaud, B. (2018). Characterization of new flavan-3-ol derivatives in fermented cocoa beans. Food Chemistry, 259(45), 207-212. DOI 10.1016/j.foodchem.2018.03.133.

39. Tang, B., Li, L., Hu, Z., Chen, Y., Chen, G. (2020). Anthocyanin accumulation and transcriptional regulation of anthocyanin biosynthesis in purple pepper. Journal of Agricultural and Food Chemistry, 68(43), 12152-12163. DOI 10.1021/acs.jafc.0c02460.

40. Reinisalo, M., Karlund, A., Koskela, A., Kaarniranta, K., Karjalainen, R. (2015). Polyphenol stilbenes: Molecular mechanisms of defence against oxidative stress and aging-related diseases. Oxidative Medicine and Cellular Longevity, 2015(2), 1-24. DOI 10.1155/2015/340520.

41. Islam, M. S., Jin, Y. Y., Chung, H. J., Kim, H. J., Baek, S. H. et al. (2019). Effect of the resveratrol rice DJ526 on longevity. Nutrients, 11(8), 1804. DOI 10.3390/nu11081804.

42. Akowuah, G., Ismail, Z., Norhayati, I., Sadikun, A. (2005). The effects of different extraction solvents of varying polarities on polyphenols of Orthosiphon stamineus and evaluation of the free radical-scavenging activity. Food Chemistry, 93(2), 311-317. DOI 10.1016/j.foodchem.2004.09.028.

43. Ćujić, N., Šavikin, K., Janković, T., Pljevljakušić, D., Ibrić, S. (2016). Optimization of polyphenols extraction from dried chokeberry using maceration as traditional technique. Food Chemistry, 194, 135-142. DOI 10.1016/ j.foodchem.2015.08.008.

44. Ramón-Gonçalves, M., Gómez-Mejía, E., Rosales-Conrado, N., León-González, M., Madrid, Y. (2019). Extraction, identification and quantification of polyphenols from spent coffee grounds by chromatographic methods and chemometric analyses. Waste Management, 96(3), 15-24. DOI 10.1016/j.wasman.2019.07.009.

45. Patial, P. K., Sharma, A., Kaur, I., Cannoo, D. S. (2019). Correlation study among the extraction techniques, phytochemicals, and antioxidant activity of Nepeta spicata aerial part. Biocatalysis and Agricultural Biotechnology, 20(6), 101275. DOI 10.1016/j.bcab.2019.101275.

46. Moreira, M., Barroso, M., Porto, J., Ramalhosa, M. (2018). Potential of Portuguese vine shoot wastes as natural resource of bio active compounds. Science of the Total Environment, 634, 831-842. DOI 10.1016/j. scitotenv.2018.04.035.

47. Cova, C., Boffa, L., Pistocchi, M., Giorgini, S., Luque, R. et al. (2019). Technology and process design for phenols recovery from industrial chicory (Chicorium intybus) leftovers. Molecules, 24, 2681-2694.

48. Chemat, F., Li, Y., Tomao, V., Ginies, C., Cravotto, G. (2014). Optimization of procedures for in-line extraction of lipids and polyphenols from grape seeds. Food Analytical Methods, 7, 459-464.

49. Khan, M., Vian, M., Fabiano-Tixier, A., Dangles, O., Chemat, F. (2010). Ultrasound-assisted extraction of polyphenols (flavanone glycosides) from orange (Citrus sinensis L.) peel. Food Chemistry, 119, 851-858.

50. Zheng, L., Yu, P., Zhang, Y., Wang, P., Yan, W. et al. (2021). Evaluating the bio-application of biomacromolecule of lignin-carbohydrate complexes (LCC) from wheat straw in bone metabolism via ROS scavenging. International Journal of Biological Macromolecules, 176, 13-25.

51. Dai, L., Huang, T., Jiang, K., Zhou, X., Xu, Y. (2021). A novel recyclable furoic acid-assisted pretreatment for sugarcane bagasse biorefinery in co-production of xylooligosaccharides and glucose. Biotechnology for Biofuels, 14, 35.

52. Dong, H., Zheng, L., Yu, P., Jiang, Q., Wu, Y. et al. (2020). Characterization and application of lignin-carbohydrate complexes from lignocellulosic materials as antioxidants for scavenging in vitro and in vivo reactive oxygen species. ACS Sustainable Chemistry \& Engineering, 8, 256-266.

53. Quitain, A. T., Katoh, S., Moriyoshi, T. (2004). Isolation of antimicrobials and antioxidants from moso-bamboo (Phyllostachys heterocycla) by supercritical $\mathrm{CO}_{2}$ extraction and subsequent hydrothermal treatment of the residues. Industrial \& Engineering Chemistry Research, 43(4), 1056-1060.

54. Escobedo-Flores, Y., Chavez-Flores, D., Salmeron, I., Molina-Guerrero, C., Perez-Vega, S. (2018). Optimization of supercritical fluid extraction of polyphenols from oats (Avena sativa L.) and their antioxidant activities. Journal of Cereal Science, 80, 198-204.

55. Buszewski, B., Rafińska, K., Cvetanović, A., Walczak, J., Krakowska, A. et al. (2019). Phytochemical analysis and biological activity of Lupinus luteus seeds extracts obtained by supercritical fluid extraction. Phytochemistry Letters, 30, 338-348. 
56. Aresta, A., Cotugno, P., Vietro, N., Massari, F., Zambonin, C. (2020). Determination of polyphenols and vitamins in wine-making by-products by supercritical fluid extraction (SFE). Analytical Letters, 53(16), 2585-2595.

57. Phan, L., Nguyen, K., Hoai, T., Tran, D., Nguyen, T. et al. (2020). Supercritical fluid extraction of polyphenols from Vietnamese Callisia fragrans leaves and antioxidant activity of the extract. Journal of Chemistry, 2020(11), 1-7. DOI 10.1155/2020/9548401.

58. Geng, W., Venditti, R., Pawlak, J., De Assis, T., Gonzalez, R. et al. (2019). Techno-economic analysis of hemicellulose extraction from different types of lignocellulosic feedstocks and strategies for cost optimization. Biofuels Bioproducts \& Biorefining-Biofpr, 14(2), 225-241. DOI 10.1002/bbb.2054.

59. Li, H., Liang, Y., Li, P., He, C. (2020). Conversion of biomass lignin to high-value polyurethane: A review. Journal of Bioresources and Bioproducts, 5(3), 163-179. DOI 10.1016/j.jobab.2020.07.002.

60. Ding, Q., Jiang, H., Chen, Y., Luo, L., He, R. et al. (2020). Influence of nitrogen protection on the extraction yield and antioxidant activities of polyphenols by ultrasonic-assisted extraction from rapeseed meal. Journal of Food Process Engineering, 42(5), e13104.1-e13104.11.

61. Oroian, M., Ursachi, F., Dranca, F. (2020). Ultrasound-assisted extraction of polyphenols from crude pollen. Antioxidants, 9(4), 322. DOI 10.3390/antiox9040322.

62. Chen, J., Fan, X. L., Zhang, L. D., Chen, X. J., Sun, S. L. et al. (2020). Research progress in lignin-based slow/ controlled release fertilizer. ChemSusChem, 13(17), 4356-4366. DOI 10.1002/cssc.202000455.

63. Grigorakis, S., Halahlah, A., Makris, D. (2020). Hydroglycerolic solvent and ultrasonication pretreatment: A green blend for high-efficiency extraction of Salvia fruticosa polyphenols. Sustainability, 12(12), 4840. DOI 10.3390/ su12124840.

64. Angoy, A., Valat, M., Ginisty, P., Sommier, A., Goupy, P. et al. (2018). Development of microwave-assisted dynamic extraction by combination with centrifugal force for polyphenols extraction from lettuce. LWT-Food Science and Technology, 98, 283-290. DOI 10.1016/j.lwt.2018.08.059.

65. Chen, X. J., Li, Z. H., Zhang, L. D., Wang, H. R., Qiu, C. Z. et al. (2021). Preparation of a novel lignin-based film with high solid content and its physicochemical characteristics. Industrial Crops and Products, 164(115), 113396. DOI 10.1016/j.indcrop.2021.113396.

66. Yu, Q., Duan, J., Yu, N., Fan, L. (2020). Enhancing the antityrosinase activity of saponins and polyphenols from Asparagus by hot air coupled with microwave treatments. LWT-Food Science and Technology, 124(1), 109174. DOI 10.1016/j.lwt.2020.109174.

67. Belwal, T., Pandey, A., Bhatt, I., Rawal, R. (2020). Optimized microwave assisted extraction (MAe) of alkaloids and polyphenols from Berberis roots using multiple-component analysis. Scientific Reports, 10(1), 917.

68. Wang, H. R., Chen, X. J., Zhang, L. D., Li, Z. H., Fan, X. L. et al. (2021). Efficient production of lignin-based slow-release nitrogen fertilizer via microwave heating. Industrial Crops and Products, 166, 113481.

69. Petrotos, K., Giavasis, I., Gerasopoulos, K., Mitsagga, C., Papaioannou, C. et al. (2021). Optimization of the vacuum microwave assisted extraction of the natural polyphenols and flavonoids from the raw solid waste of the pomegranate juice producing industry at industrial scale. Molecules, 26, 1033.

70. Saad, N., Louvet, F., Tarrade, S., Meudec, E., Grenier, K. et al. (2019). Enzyme-assisted extraction of bioactive compounds from raspberry (Rubus idaeus L.) pomace. Journal of Food Science, 84(6), 1371-1381.

71. Shankara, K., Kulkarnia, N., Jayalakshmib, S., Kuruba, S. (2019). Comparative assessment of solvents and lignocellulolytic enzymes affiliated extraction of polyphenols from the various lignocellulosic agro-residues: Identification and their antioxidant properties. Preparative Biochemistry \& Biotechnology, 50, 164-171.

72. Domínguez-Rodríguez, G., Marina, M., Plaza, M. (2021). Enzyme-assisted extraction of bioactive non-extractable polyphenols from sweet cherry (Prunus avium L.) pomace. Food Chemistry, 339, 128086.

73. Bretag, J., Kammerer, D., Jensen, U., Carle, R. (2009). Adsorption of rutin onto a food-grade styrenedivinylbenzene copolymer in a model system. Food Chemistry, 114, 151-160.

74. Kammerer, D., Carle, R., Stanley, R., Saleh, Z. (2010). Pilot-scale resin adsorption as a means to recover and fractionate apple polyphenols. Journal of Agricultural and Food Chemistry, 58, 6787-6796.

75. Fu, R., Wang, Y., Yu, F., Wu, X., Gua, Y. et al. (2015). Optimization of the macroporous resin-based adsorption of apple polyphenol through response surface methodology. Toxicological and Environmental Chemistry, 98, 479-491. 
76. Xin, Q., Zhang, X., Lei, L. (2008). Inactivation of bacteria in oil-field reinjection water by pulsed electric field (PEF) process. Industrial \& Engineering Chemistry Research, 47(23), 9644-9650.

77. Liu, Z., Esveld, E., Vincken, J., Bruins, M. (2019). Pulsed electric field as an alternative pre-treatment for drying to enhance polyphenol extraction from fresh tea leaves. Food and Bioprocess Technology, 12(1), 183-192. DOI 10.1007/s11947-018-2199-x.

78. Barbosa-Pereira, L., Guglielmetti, A., Zeppa, G. (2018). Pulsed electric field assisted extraction of bioactive compounds from cocoa bean shell and coffee silver skin. Food and Bioprocess Technology, 11(4), 818-835. DOI 10.1007/s11947-017-2045-6.

79. López-Gámez, G., Elez-Martínez, P., Martín-Belloso, O., Soliva-Fortuny, R. (2020). Enhancing phenolic content in carrots by pulsed electric fields during post-treatment time: Effects on cell viability and quality attributes. Innovative Food Science \& Emerging Technologies, 59(7), 102252. DOI 10.1016/j.ifset.2019.102252.

80. Maza, M., Martínez, J., Hernández-Orte, P., Cebrián, G., Sánchez-Gimeno, A. et al. (2019). Influence of pulsed electric fields on aroma and polyphenolic compounds of Garnacha wine. Food and Bioproducts Processing, 116(3), 249-257. DOI 10.1016/j.fbp.2019.06.005.

81. Comuzzo, P., Voce, S., Grazioli, C., Tubaro, F., Marconi, M. et al. (2020). Pulsed electric field processing of red grapes (cv. Rondinella): Modifications of phenolic fraction and effects on wine evolution. Foods, 9(4), 414. DOI 10.3390/foods 9040414.

82. Lončarić, A., Celeiro, M., Jozinović, A., Jelinić, J., Kovač, T. et al. (2020). Green extraction methods for extraction of polyphenolic compounds from blueberry pomace. Foods, 9(11), 1521. DOI 10.3390/foods9111521.

83. Andreou, V., Psarianos, M., Dimopoulos, G., Tsimogiannis, D., Taoukis, P. (2020). Effect of pulsed electric fields and high pressure on improved recovery of high-added-value compounds from olive pomace. Journal of Food Science, 85(5), 1500-1512. DOI 10.1111/1750-3841.15122.

84. Ricci, A., Parpinello, G., Banfi, B., Olivi, F., Versari, A. (2020). Preliminary study of the effects of pulsed electricfield (PEF) treatments in wines obtained from early-harvested Sangiovese grapes. Beverages, 6(2), 34. DOI 10.3390/beverages6020034.

85. López-Gámez, G., Elez-Martínez, P., Martín-Belloso, O., Soliva-Fortuny, R. (2020). Enhancing phenolic content in carrots by pulsed electric fields during post-treatment time: Effects on cell viability and quality attributes. Innovative Food Science \& Emerging Technologies, 59(7), 102252. DOI 10.1016/j.ifset.2019.102252.

86. Feuereisen, M. M., Barraza, M. G., Zimmermann, B. F., Schi Eb Er, A., Schulze-Kaysers, N. (2017). Pressurized liquid extraction of anthocyanins and biflavonoids from schinus terebinthifolius raddi: A multivariate optimization. Food Chemistry, 214, 564-571. DOI 10.1016/j.foodchem.2016.07.002.

87. Corazza, G. O., Bilibio, D., Zanella, O., Nunes, A. L., Bender, J. P. et al. (2018). Pressurized liquid extraction of polyphenols from Goldenberry: Influence on antioxidant activity and chemical composition. Food and Bioproducts Processing, 112, 63-68. DOI 10.1016/j.fbp.2018.09.001.

88. Queiroz, C., Lopes, M. L. M., Silva, A. J. R. D., Fialho, E., Valente-Mesquita, V. L. (2021). Effect of high hydrostatic pressure and storage in fresh-cut cashew apple: Changes in phenolic profile and polyphenol oxidase activity. Journal of Food Processing and Preservation, 45(10), 85. DOI 10.1111/jfpp.15857.

89. Grassino, A. N., Ostoji, J., Mileti, V., Djakovi, S., Bosiljkov, T. et al. (2020). Application of high hydrostatic pressure and ultrasound-assisted extractions as a novel approach for pectin and polyphenols recovery from tomato peel waste-sciencedirect. Innovative Food Science \& Emerging Technologies, 64, 102424. DOI 10.1016/j.ifset.2020.102424.

90. Mushtaq, M., Sultana, B., Akram, S., Anwar, F., Adnan, A. et al. (2017). Enzyme-assisted supercritical fluid extraction: An alternative and green technology for non-extractable polyphenols. Analytical and Bioanalytical Chemistry, 409(14), 3645-3655. DOI 10.1007/s00216-017-0309-7.

91. Kantar, S., Boussetta, N., Rajha, H., Maroun, R., Louka, N. et al. (2018). High voltage electrical discharges combined with enzymatic hydrolysis for extraction of polyphenols and fermentable sugars from orange peels. Food Research International, 107(1), 755-762. DOI 10.1016/j.foodres.2018.01.070. 
92. Borda-Yepes, V., Janna, F., Daza-Olivella, L., Arbelaez, A., Rojano, B. et al. (2018). Effect of microwave and infrared drying over polyphenol content in Vaccinium meridionale (Swartz) dry leaves. Journal of Food Process Engineering, 42(1), e12939.

93. Fu, X., Ma, N., Sun, W., Dang, Y. (2018). Microwave and enzyme co-assisted aqueous two-phase extraction of polyphenol and lutein from marigold (Tagetes erecta L.) flower. Industrial Crops and Products, 123, 296-302.

94. Trujillo-Mayol, I., Cespedes-Acuña, C., Silva, F., Alarcon, J. (2019). Improvement of the polyphenol extraction from avocado peel by assisted ultrasound and microwaves. Journal of Food Process Engineering, 42(6), e13197.

95. Nag, S., Sit, N. (2018). Optimization of ultrasound assisted enzymatic extraction of polyphenols from pomegranate peels based on phytochemical content and antioxidant property. Journal of Food Measurement and Characterization, 12(3), 1734-1743.

96. Nishad, J., Saha, S., Kaur, C. (2019). Enzyme- and ultrasound-assisted extractions of polyphenols from Citrus sinensis (cv. Malta) peel: A comparative study. Journal of Food Processing and Preservation, 43(4), e14046.1e14046.13.

97. Balasubramaniam, V., Palani, A., Sathvika, S., Antony, U. (2019). Effect of enzyme pretreatment in the ultrasound assisted extraction of finger millet polyphenols. Journal of Food Science and Technology, 56(3), 1583-1594.

98. Olawuyi, I., Akbarovich, S., Kim, C., Lee, W. (2020). Effect of combined ultrasound-enzyme treatment on recovery of phenolic compounds, antioxidant capacity, and quality of plum (Prunus salicina L.) juice. Journal of Food Processing and Preservation, 45(1), e15074.

99. Fernández-Ponce, M., Medina-Ruiz, E., Casas, L., Mantell, C., Ossa-Fernández, E. (2018). Development of cotton fabric impregnated with antioxidant mango polyphenols by means of supercritical fluids. Journal of Supercritical Fluids, 140, 310-319. 